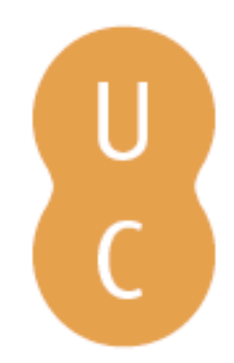

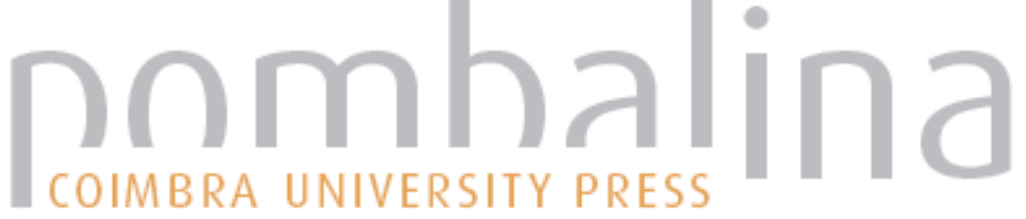

\section{Representations of Alexandria in Classical Latin Literature}

Autor(es): $\quad$ Pimentel, Maria Cristina de Castro-Maia de Sousa

$\begin{array}{ll}\text { Edições Afrontamento; CITCEM - Centro de Investigação } \\ \text { Publicado por: } & \begin{array}{l}\text { Transdisciplinar «Cultura, Espaço e Memória»; Centro de Estudos } \\ \text { Clássicos e Humanísticos; Alexandria University; Imprensa da } \\ \text { Universidade de Coimbra }\end{array}\end{array}$

URL persistente:

URI:http://hdl.handle.net/10316.2/36157

DOI:

DOI:http://dx.doi.org/10.14195/978-989-26-0966-9_3

Accessed : $\quad$ 26-Apr-2023 13:56:53

A navegação consulta e descarregamento dos títulos inseridos nas Bibliotecas Digitais UC Digitalis, UC Pombalina e UC Impactum, pressupõem a aceitação plena e sem reservas dos Termos e Condições de Uso destas Bibliotecas Digitais, disponíveis em https://digitalis.uc.pt/pt-pt/termos.

Conforme exposto nos referidos Termos e Condições de Uso, o descarregamento de títulos de acesso restrito requer uma licença válida de autorização devendo o utilizador aceder ao(s) documento(s) a partir de um endereço de IP da instituição detentora da supramencionada licença.

Ao utilizador é apenas permitido o descarregamento para uso pessoal, pelo que o emprego do(s) título(s) descarregado(s) para outro fim, designadamente comercial, carece de autorização do respetivo autor ou editor da obra.

Na medida em que todas as obras da UC Digitalis se encontram protegidas pelo Código do Direito de Autor e Direitos Conexos e demais legislação aplicável, toda a cópia, parcial ou total, deste documento, nos casos em que é legalmente admitida, deverá conter ou fazer-se acompanhar por este aviso. 


\title{
REPRESENTATIONS OF ALEXANDRIA IN CLASSICAL LATIN LITERATURE
}

\author{
MARIA CRISTINA DE CASTRO-MAIA DE SOUSA PIMENTEL
}

University of Lisbon. Centro de Estudos Clássicos (University of Lisbon).

\begin{abstract}
Our paper intends to focus on Alexandria after the Roman annexation: what traces of its splendour and glory do we find in classical Latin literature? What repercussions of the changes suffered after 30 B.C. called the attention of these authors? What did the Romans think of the inhabitants of Alexandria, and what relationship did they have with the history of that part of the world? Greek literature is rich in information on Egypt and Alexandria, but from this image of a magnificent city that the Greeks have left us, what do the Latin authors echo? What is made of its population, Greeks, Egyptians, Syrians, Jews, people coming from all parts of the world? The portrait we can trace is, of course, imperfect. To get as close as possible to Roman Egypt, we would have to rely on the information provided by Greek Literature, by Papyrology, Numismatics, Epigraphy, Archaeology, reading ostraka, etc. We will try, however, to list this information according to different thematic areas, such as: The description of the city; The wonders of Alexandria; The way the Alexandrians are seen and portrayed by the Roman authors; The history of Alexandria and its relations with Rome; What the Romans got from Egypt and Alexandria; What the Alexandrians got from the Romans; The attraction of Alexandria and Egypt among the Romans.
\end{abstract}

When, on August 1 of the year 30 B.C., Octavian, having taken Alexandria, entered the city on foot, while engaged in casual conversation with one of the Museum's philosophers, his attitude was characteristic of the meticulousness with which, at this time, a certain 
amount of political stage managing took place in order to build up the reputation and political power of public figures. Augustus' gesture had the appearance of a peaceful entry, a mission of somebody who was not coming to annex or subjugate the ancient and splendid land of the Pharaohs and the Ptolemies, and its capital Alexandrea ad Aegyptum, the magnificent city which Alexander, in the already distant days of 331 B.C., had dreamed of and ordered to be built. Defeated, Mark Anthony took his own life and Cleopatra VII, the seductive and stubborn queen of Egypt, proud of her ancestral lineage and with her ambitions thwarted, avoided, also by suicide, the unbearable humiliation of coming to join, alive, the triumphant procession, which, as she knew well, the winner of Actium was to celebrate in Rome. Octavian, certain that Egypt was irreversibly under Roman rule, goes on to attach it to the already vast territories of Rome, and gives it special administrative status, which will ensure control of what is now the largest source of income, in assets and in taxes, among all the provinces under the aegis of the princeps.

But what did that peaceful entry mean for Egypt and specifically for Alexandria? What happened afterwards to the city which was the second metropolis of the world, surpassed only by Rome? What destiny did the annexation trace for the province and its inhabitants? It is true that Rome was not an alien power in Egypt. Ever since, in the 3rd century B.C., King Ptolemy II sent an embassy to Rome, which the Romans reciprocated, the path was open for Rome to recognise itself the right, during the following two centuries, to intervene in the frequent dynastic conflicts or against external threats (whether upon request or by clauses set forth in the testaments of the kings of Egypt, or whether by Rome's own decision). Thus, Egypt was turned into a protectorate that very soon, because of its wealth and commercial potential, became an attractive target for men with imperial aspirations. A long series of diplomatic episodes and some bloody military conflicts, such as the war of Alexandria, which, a little more than two decades before the annexation of the province, Julius Caesar had taken on in order to restore Cleopatra on the Ptolemaic throne, had marked the history of the already declining Lagid Dynasty and contributed to the image that the Egyptian and Greek populations had of Rome - a negative image which allowed them to foresee that their impending destiny was the loss of autonomy and freedom.

In 30 B.C., therefore, Octavian lays the groundwork for the administration of Egypt and its capital city. He takes advantage of the complex bureaucratic structure with its strong hierarchies, inherited from the Ptolemaic Dynasty, and makes the adaptations that he deems necessary. In a word: what works, according to the pragmatic and efficient perspective of the Roman centralised power, remains; what does not work or does not serve the interests of the Romans, is cancelled and replaced. Important additions are made, such as the institution of the praefectus Alexandriae et Aegypti, an eques who represents and answers only to the emperor, having vested in him extraordinary powers to ensure supervision of all political, economic, legal, social and even military functions. Octavian, who retains direct power over the new province, immediately takes precautions, aware of the danger 
that the control of Egypt could represent for Rome, if somebody, put in charge of the administration of the province, plotted or headed a seditious movement or merely decided to oppose Rome, cutting off its grain supply, the base for the survival of the plebs and, thus, the guarantee of its remaining under control and away from riots and social unrest. Octavian Augustus was so certain that he needed to prevent members of the highest social strata from accessing Egypt, where they could conceive and execute plans of insurgency, that he forbade senators and knights of senatorial status to enter Egypt without the express and prior authorisation of the princeps.

Let us focus, then, on Alexandria after the Roman annexation: what traces of its splendour and glory do we find in classical Latin literature? What repercussions of the changes suffered after 30 B.C. called the attention of these authors? What did the Romans think of the inhabitants of Alexandria, and what relationship did they have with the history of that part of the world? Let us recall that Strabo (Book 17) gave us the most complete description of the capital of Egypt, a city he saw with his own eyes, and with which he felt fascinated, a few years after its annexation by Rome. Diodorus Siculus (17.52), who had also visited Alexandria, expresses, although more succinctly, the attraction that the city, so beautiful and organized, exerted on those who saw it. Other authors, such as Theocritus in the celebrated Idyll XV, show us the hustle and bustle of a city full of people, involved in religious ceremonies or other celebrations, in a vibration of life that still touches us today.

Greek literature is rich in information on Egypt and Alexandria, but from this image that the Greeks have left us, what do the Latin authors echo? What is made of the Museum, its two libraries - the principal and the one of the Serapeum - the royal palace, the Sema, the tomb of Alexander, the wide and perpendicular streets, the five districts named after the first five letters of the Greek alphabet, the two sea ports and the channel that brought the waters of the Nile, the tower of the island of Pharos which guided sailors and shone its light in a radius of fifty kilometres, and of the heptastadion which connected the island to the mainland? What is made of its population, Greeks, Egyptians, Syrians, Jews, people coming from all parts of the world, with their frequent conflicts but also with the inevitable crossing of cultures that was enriching for all?

The perspective of Latin authors is naturally consistent, in most cases, with what we would expect from people who belong, with more or less explicitly stated pride, to the nation that was victorious at Actium and had conquered the world, and who believed themselves to be the keepers of civilization in its purest and highest form. The portrait we can trace is, however, imperfect. To get as close as possible to Roman Egypt, we would have to rely on the information provided by Greek Literature, by Papyrology, Numismatics, Epigraphy, Archaeology, reading ostraka, etc. Let us try, however, to list this information according to different thematic areas. 


\section{THE DESCRIPTION OF THE CITY}

In Latin literature, as far as we know, only Ammianus Marcellinus (22.16), as late as the 4th century A.D., gives us a description of Alexandria, which he calls the «pearl» of all cities. He tells us of its numerous and magnificent constructions, built thanks to the generosity of Alexander and the art of the architect Dinocrates. He mentions its beautiful and great walls and the abundance announced at the time of its foundation by portents of future wealth. $\mathrm{He}$ reminds us of the mild climate, the healthy breezes and the invariably clear sky. He recalls the high tower called «Pharos», which, with gross anachronism, he attributes to Cleopatra, who, according to him, planned and built it in the port, to provide assistance to ships with its light, and thus put an end to the hitherto frequent shipwrecks. He celebrates the heptastadion, notable not only for its length but also for the speed with which it was constructed, according to him also by Cleopatra. He alludes to the temples with the high ceilings, such as the Serapeum, superb in its rooms filled with columns, with statues that appeared to be alive, and so decorated with works of art that after the Capitol in Rome there was, in his opinion, nothing more wonderful in the face of the earth. Finally, he speaks of the two libraries of the city, which were invaluable and in which had been deposited thanks to the efforts of the Ptolemies seven hundred thousand volumes, he then refers to the fire that consumed them during the war of Alexandria, when the city was sacked by Julius Caesar.

Ammianus also speaks of Canopus, a town twelve miles from Alexandria, situated in a pleasant and salubrious location, where everybody experienced the feeling of being away from worldly things. In the context of this extensive digression, which had begun with an overview of Egypt, its fauna and the major monuments, the administrative divisions and its special type of government by a praefectus, its cities, and the bizarre way of writing of the Egyptians, there are also references to the huge expanse of Alexandria, which was reached not gradually, as it happens with ordinary cities, but right from the outset. The historian also notes that at the time of emperor Aurelian, when conflicts between citizens became devastating battles, the city ended up, plagued by continuous internal unrest, having its walls in ruins and suffering the loss of a part of the city where many illustrious men lived from time immemorial. Of these, the historian evokes some names from ancient times, to affirm immediately afterwards that, in his time, in Alexandria there were still many who had distinguished themselves in the Arts, Geometry, Music, Astronomy, Mathematics, Divination, and above all, Medicine. At the end of this curious digression and before reminding us, rather simplistically, that in Antiquity the whole of Egypt was a monarchy allied with Rome, converted into a province under the rule of Octavian after the defeat of Anthony and Cleopatra at the battle of Actium, Ammianus draws a sketch of the physical characteristics and character of the Egyptians, saying that they are almost all swarthy and have quite dark skin, looking a little sad, slender, dry, hot-headed, rebellious and very insistent when they complain about something. He also notes that they refused to pay taxes, and that they 
endured physical punishment for not doing so. The worst tortures could not make them confess their crimes.

As a necessarily brief comment, we can say that what calls our attention in this excursus is what we read of the survival, however diminished but still evident, of the grandeur of yesterday, as well as the distrusting and xenophobic perspective of somebody who sees «the Other» as people in obstinate rebellion and infringement, people who do not fit the standards of civilization imposed by Rome to the world. Also significant is the default reading of the political regime under which Egypt lived throughout its history, as only the monarchy's alliance with Rome is evoked, and then the submission to Augustus after the resounding victory of Actium. In this view, Ammianus is the heir of all the Latin literary tradition that precedes him.

\section{THE WONDERS OF ALEXANDRIA}

Roman authors are not sparing in their praise of the beauty and grandeur of the capital of Egypt. Among others, the Bellum Alexandrinum (3.1) speaks of the "[V]rbs fertilissima et copiosissima». Cicero, in De Lege Agraria (2.43) uses three superlatives to describe Alexandria and Egypt: "[urbis] copiosissimae; opulentissimi [regni]; pulcherrimorum [agrorum]» ${ }^{1}$. The lighthouse on the island of Pharos, one of the seven wonders of the ancient world, also could not have left the Romans indifferent. Pliny (NH 36.83), for example, praises the «turris a rege facta in insula Pharo», and, with instructive zeal, tells us that the cost of the work rose to 800 talents. The royal palace, which had attracted the admiration of Theocritus, is the subject of description in Lucan (BC 10.111-126), who evokes, although with no direct knowledge, the wealth and grandeur of the building and its decoration. The mausoleum of Alexander, in the interior of which reposed the body of the city's founder, had been laid to rest, embalmed and anointed with honey (cf. Statius, Silu. 3.2.118), and which was also the tomb of the Ptolemies, is equally mentioned by several Latin authors, such as Lucan (BC 10.1-51).

Inevitably, the fabulous Library of Alexandria elicited references in classical Latin literature. Seneca, in a moralist tone, evokes the burning of the collection of more than forty thousand uolumina in 47 B.C., that is, during the war of Alexandria. He does not attach liability to Caesar, but, while acknowledging that it was pulcherrimum regiae opulentiae monumentum (Tranq. 9.5), he gives a verdict consistent with Stoic obedience which leads him to say that, if there are those who praise such magnificence, he himself does not see in it neither cura nor elegantia, but only a studiosa luxuria: so many books and so much wealth

\footnotetext{
${ }^{1}$ Cf. also NH 5.62-63: not stopping short of an encomium, Pliny does not fail to consider worthy of praise (iure laudetur in litore Aegyptii maris Alexandria) the capital of Egypt, whose boundaries and shape he briefly describes, also including a reference to the extent of the royal palace, which occupied one fifth of the city.
} 
were just in spectaculum, meant as the ornament and ostentation of power. Vitruvius (7.4-5) speaks in a more detached tone and praises the intentions of the founder of the Library, who must have acted with infinito zelo, eager to expand the practice of reading and the knowledge of great works and to spread culture. Regarding the controversial issue of the burning of the Library, which some attribute to an involuntary act of Julius Caesar and others think that never even happened, the information actually found in Latin literature does not allow us to clarify the truth of the matter. Florus (2.13) sticks to the non-specific statement that Caesar, in order to repel the onslaught of the enemy, set fire to buildings (without saying which) near the place where he was in the city, as well as to the arsenal and the port, and then took refuge on the island of Pharos. This version derives directly from what Caesar himself had written ( $B C$ 3.111), which speaks of setting fire to the ships for defence purposes, but does not say whether the fire spread and consumed the Library. The omission is perhaps not surprising: if it indeed had happened in this way, Caesar, the general and man of culture, would not have a reason to be proud of the incident. To defend his image, he would have tried to conceal such misfortune. As we have seen, Ammianus Marcellinus (22.16.13) links the burning of the Library to the sack of the city carried out by Caesar, and refers to the destruction of seven hundred thousand volumes. This is also the number mentioned by Aulus Gellius (NA 7.17.3): this erudite man does not err in attributing the founding of the Library to the Ptolemies, and makes a point of mentioning that the fire occurred during the sack of Alexandria in the war started by Caesar, but that there was no express order to ignite it, immediately adding the hypothesis that the auxiliary soldiers were the ones to do so.

The natural characteristics that made Alexandria a city ideally suited to occupy the place of prominence it held also did not escape the attention of the Latin writers. As good Romans, aware of the strategic importance of geographic location, they often referred to the fact that Alexandria was closed up and naturally defended against attacks and enemy incursions. The Bellum Alexandrinum speaks of this favourable location using the word claustrum (26.2) to refer to the advantage of the city being guarded by the island of Pharos from the side of the sea, and by Pelusium from the side of the land ${ }^{2}$.

\section{THE ALEXANDRIANS: TREACHEROUS, INDOMITABLE, CONFRONTATIONAL, AMBITIOUS, INSOLENT AND PROFLIGATE}

This is the image of the Alexandrians in particular, and the Egyptians in general, that emerges from Latin literature and comes from texts even prior to the annexation. The

\footnotetext{
2 The same word is used, and with exactly the same intention, by Liv. 45.11.5; Luc., BC 10.509; Tacitus, Hist. 2.82; and Suet., Vesp. 7.2.
} 
author of the Bellum Alexandrinum describes them as aptissimi ad proditionem (cf. 7.3), calls them fallaces and temerarii (7.2) - repeating the adjective fallax in 24.1 (fallacem gentem) - people who always think in one way and act in another (24.1: semperque alia cogitantem alia simulantem). Seneca (Breu. 13.7) underlines the perfidia that characterised the Alexandrians, evident in the brutal and treacherous murder of Pompey ${ }^{3}$.

Cicero, for example, in the Pro Rabirio Postumo (34-36) speaks of the insolence of the Alexandrians, and criticises their os and the audacia with which they now assert what they have just denied. He disparages their lying, impertinence, and the constant prestigiae and fallaciae, which they use and abuse ${ }^{4}$.

A passage by Frontinus (1.1.5), from his chapter De occultandis consiliis, is significant. Here he recounts that Caesar, while preparing the war of Alexandria, suspicious of its inhabitants but wanting to appear aloof and disinterested, and while inspecting the city and its defences, surrendered to licentioribus conuiuiis, to riotous banquets, pretending he was captivated by the charms of the city and that he had allowed himself to take on the habits and lifestyle of its inhabitants - attached to the deliciae Ovid speaks of (Tristia 1.2.80) and the otia laeta which Valerius Flaccus celebrates (5.422). Frontinus then turns to attack the Alexandrians, seen as a people abandoned to the most common pleasures ${ }^{5}$.

Viewed with surprise and some irony or disgust, the Romans also refer to the incestuous relations, which, they said, were common in Egypt. Seneca speaks (Apoc. 8.2-3) of incest between siblings, obviously alluding to royal marriages, but generalising the practice to the entire city of Alexandria.

There are also various statements about the confrontational and hot-tempered character of the Alexandrians. One example is what is said of the Egyptians, and applies to the natives of Alexandria, in the Historia Augusta (Tyranni Triginta 22): they were people who put the state at serious risk for minor things.

To lighten up the dark colours of this portrait, there are, however, authors who do not hide certain qualities and skills of the Alexandrians. A doubt remains, nevertheless, whether such praise does not often serve above all for the aggrandisement of those who won and dominated over them. In the Bellum Alexandrinum $(3.1 ; 13.2 ; 16.5)$ it is said that they are homines ingeniosi atque acutissimi, possessed of such naturalis sollertia that they were able to reproduce everything they saw the Romans doing, and then imagine sponte sua many attack and defence mechanisms, as well as how to distinguish themselves in the war at sea. The characterisation we get in the Historia Augusta (Quadrigae Tyrannorum 9.8) is of an industrious and hard-working people. An alleged letter of Hadrian is reproduced here, which speaks of Alexandria as a thriving city, rich and fertile, where nobody

\footnotetext{
${ }^{3}$ Cf. also B. Al. 24.3; Prop. 3.11.33; Sen., Ad Marc. 20.4.

${ }^{4}$ Cf. also Sen., Ad Helu. 19.6; Quint. 1.2.7; Suet., Vesp. 19.2.

${ }^{5}$ Cf. Juv. 6.82-84 and, on Canopus, Prop. 3.39; Sen., Epist. 51.3; Juv. 15.46.
} 
can live idle: some blow glass, others work in the confection of paper, all are skilled weavers of linen, the most skilled among all nations. Everybody works, even the disabled and the eunuchs. After this apparently flattering description, criticism creeps in, in the statement that the only god of the Alexandrians, whether they be Christian, Jew or Gentile, is money.

\section{THE HISTORY OF ALEXANDRIA AND ITS RELATIONS WITH ROME}

We have to make reference, on the one hand, to the period before the annexation, and on the other, to the events and circumstances after 30 B.C. Prior to this date most significant are the passages on the several interventions of Rome in Ptolemaic politics, as well as on the foundation of Alexandria by Alexander the Great, following a dream he had after returning from the temple of Ammon at Siwa, where he was recognised as a son of the god. Latin authors such as Quintus Curtius (4.8.5-6) repeat the episode where Alexander marked the borders of the city (using flour), and they tell how birds came to eat some of this flour. Alexander was struck, because he read in what had happened a negative omen, but soon the seers managed to deflect this disastrous interpretation; the behaviour of the birds meant, on the contrary, something very auspicious: the future greatness of the city, rich in grain and resources that would ensure the welfare of natives and foreigners, and attract people from all parts of the world.

There is a plethora of references to the time, in the year 55 B.C., when Aulus Gabinius, proconsul of Asia, took on the mission of restoring Ptolemy XIII Auletes to the throne of Egypt. Having achieved this objective, Gabinius left one legion in Alexandria, to protect the king. The troops soon became accustomed to the softness and licentia of local habits, settled with Egyptian women and had children, lost their nerve and the discipline that guaranteed the strength of the Roman army. Still, five hundred knights from this legion came to join the army that Pompey gathered for the civil war ${ }^{6}$.

As it would be expected, there are also several references to the flight of Pompey to Egypt, after Pharsalus, and the reasons that led him to choose the Ptolemaic court and Alexandria as a place of refuge. Keeping in mind the favours that the Egyptian king owed him $^{7}$, Pompey thought that he would be safe there, counting on a debt of gratitude that proved nonexistent. Of course, there are numerous echoes of the death of Pompey, a shameful act perpetrated at the behest of a treacherous and ungrateful king. There are also

\footnotetext{
${ }^{6}$ Cf. Caes., BC 3.4.4; 103.3-5; 110-112. About the background of this episode, see Cic., Ad Familiares 1.5a.3-4; 1.5b.1; 1.7.4; Harusp. Resp. 34; Pro Caelio 23; 51; Ad Att. 2.16.2; Ad Quint. 2.2.3.

${ }^{7}$ Caes., BC 3.103.3: pro hospitio atque amicitia. Cf. also Vell. 2.53.1-2.
} 
echoes of the outraged reaction of Julius Caesar in Alexandria, when the head of Pompey was brought to him $^{8}$.

About the war of Alexandria, when Julius Caesar, in the city for several months, undertook the struggle with the objective of restoring as sovereign on the throne those who Ptolemy XII had appointed in his will as his heirs and successors, we can read two works which are most informative: the Bellum Alexandrinum, by an unknown author, and Julius Caesar's own Bellum Ciuile. But there are several authors who refer to this war episode. With regard to the will of Ptolemy, some find in it reason enough for Caesar's military action and justification for the support given, at that time, to Cleopatra. But everything changes when we come to the connection between Mark Anthony and Cleopatra and his intention, much to the delight of the queen, to make Alexandria the capital of the empire. It would be impossible to list here all the passages where we find the condemnation of the triumvir and his royal concubine, the joy and exaltation of Octavian after the victory at the battle of Actium, as well as references to the triumph, which the future Augustus celebrated in Rome, in the year 29 B.C. ${ }^{9}$, in which, at the absence of Cleopatra as a living prisoner, he paraded an effigy of the queen with the two asps that had brought about her death.

\section{WHAT THE ROMANS GOT FROM EGYPT AND ALEXANDRIA}

There are many echoes of what the annexation of Egypt and the knowledge and use of its assets and resources meant for Rome. If we go through the medical works of Scribonius Largus or Celsus, or Pliny's Naturalis Historia, or the compilation of cookery recipes by Apicius, we will find a huge number of remedies and recipes which contain products coming from the fauna and flora of Alexandria ${ }^{10}$. From other references we perceive the great intensity of the trade, which brought from Alexandria to Rome types of food that were considered delicacies ${ }^{11}$. From the capital of Egypt also came flowers and ornamental plants, which beautified Rome or added refinement to banquets and gatherings ${ }^{12}$.

Alexandria is also assumed to be a place whose climate is extremely beneficial to health. As a treatment for tuberculosis, Celsus (3.22.8) recommends a change of scenery -

\footnotetext{
${ }^{8}$ Cf. Caes., BC 3.106.4. The perspective of Lucan is different (as it is known, he is hostile to Caesar). According to BC 9.1035 ff., the tears of Caesar were hiding his immense joy at seeing his enemy assassinated.

${ }^{9}$ Cf. Prop. 2.1.30-34; Suet., Aug. 22.1; Serv., In Vergilii Aeneidos libros 8.714. Caesar also celebrated a triumph over Alexandria (cf. Vell. 2.56.1-2; Suet., Iul. 37.1).

${ }^{10}$ Larg., Compositiones 24; 72; 74; 231; Cels. 5.19.17; 24.1; 26.23; 27.1; Apic., De Re Coquinaria 3.4.3; 4.1.3; 10.1.6-8; Col., RR 11.3.48; Plin., NH 21.183; 22.34-36.

${ }^{11}$ Plin., NH 14.102; 15.70; 32.150; Mart. 13.122; Juv. 13.85. About Alexandrian products used in the adulteration of other products, cf. Plin., NH 12.27-29 and 20.200-201.

${ }^{12}$ Cf. Plin., NH 21.47; Stat., Silu. 2.1.161; 6.87; Mart. 6.80.
} 
the possibility considered most advantageous being a journey to Alexandria. That is exactly what Seneca did, who spent six years with his maternal aunt and her husband, so that the mild climate, constant throughout the year, would help restore his ailing health (Ad Helu. 12.19).

From Alexandria to Rome also came slaves, who were sold in the markets of the capital along with many other goods brougth from there. Many of these servants were renowned for their artistic skills ${ }^{13}$. In the houses of wealthy Romans (who had varying degrees of culture), there were Alexandrian slaves who played musical instruments, sang, acted, or served at the table, like the pueri at the banquet in the house of Trimalchion (Sat. 31.3; 68.3). Others were purchased for sexual purposes. Alexandrian slaves were supposed to excel in these favours because of their lust, as well as their learned jokes and studied words (cf. Statius, Silu. 2.1.73-75; 5.5.66-69).

But it was not just the slaves who came to give a touch of Alexandrian luxury and refinement (or depravity) to the Roman domus. In condemnation of the ostentation and luxury that dominated his time, Seneca (Epist. 86.5-7) affirms that nobody worth his salt could do without Alexandrian marble for the decoration of his home. More than houses, it was Rome that embellished itself with what came from Alexandria. Obelisks, the Ptolemaic royal treasure, and numerous works of art were brought for the decoration of the Urbs ${ }^{14}$. And for the uenationes, exotic animals were also brought to Rome, coming, not exclusively, but in great abundance from North Africa ${ }^{15}$.

The immense wealth of Alexandria came to Rome transported in the naues alexandrinae, which Seneca describes for us (Epist. 77.1), when he sees them arriving at Puteoli. They carried mail correspondence, passengers, merchandise, and above all, the grain that sustained the city. One third of the grain supply for Rome was secured with shipments from Egypt, concentrated in large silos in Alexandria and then transported to Puteoli or the port of Ostia. If the ships did not arrive, it would mean hunger, and so it is no wonder that people joined in celebration to see them enter the port. It is also not surprising that so many precautions were taken, as we have already mentioned, for the control of Egypt not to pass to the hands of those who could misuse it, especially given the possibility of blocking the grain supply to Rome. Suffice it to say that even Vespasian thought of doing just that. Having received the news of the defeat of the army of Vitellius and the massacre at the city of Cremona when he was in Egypt coming from Judaea, Vespasian rushed towards Alexandria and pondered on suspending the supply of grain that would feed the troops of Vitellius, stationed in Rome, as a way to hasten the defeat of his opponent (Tacitus, Hist. 3.48).

\footnotetext{
${ }^{13}$ Cf. Stat., Silu. 2.1.73-75; Tac., Ann. 14.60; S.H.A., Ver. 8.11.

${ }^{14}$ Cf., for example, Cic., In Verrem, actio 2.5, 145; Plin., NH 35.131-2; 36.67; 69; Suet., Aug. 41.1; 71.1; Cl. 20.3; S.H.A., Ver. 5.1-3.

${ }^{15}$ Cf., e.g., Cic., In Verrem, actio 2.5.145; Plin., NH 35.131-2; 36.67; 69; Suet., Aug. 41.1; 71.1; Cl. 20.3; S.H.A., Ver. 5.1-3.
} 
Besides grain, Rome received - and controlled exclusively - the production and trade of papyrus (cf., e.g., Pliny, NH 13.68-73).

Egypt also became a place advantageous and conducive to business, not only for members of the imperial household, but also for many of those who belonged to the privileged social strata, such as Seneca (Epist. 77).

Finally, we must recall the heavy taxes that fell on all activities - agricultural, industrial, administrative - and almost every circumstance of life, heavily taxed to benefit the coffers of Rome. A careful record of everything one had and produced was a document necessary for the tax authorities, which took charge of collecting all dues. In this respect, the Egyptians would not have found the change of government very strange: the difference, compared to the times of the Ptolemies, was only one: before 30 B.C. the taxes that crushed the population went to the royal coffers of Alexandria; after the annexation they went directly to Rome. This was a burden that never appealed to the Alexandrians and led to many revolts.

\section{WHAT THE ALEXANDRIANS GOT FROM THE ROMANS}

Given what we read in Latin authors, we are almost tempted to believe that the Romans brought few beneficial changes to Alexandria, and that impression seems to be confirmed when we read about the hatred the Alexandrians felt for their new masters and the law that was imposed on them. We cannot say that the hatred was mutual, but rather that the Romans had an attitude of distrust, disgust and surprise towards the Egyptians: because of some habits, their own form of writing, the zoolatry, and other aspects of their religion. Moreover, it is not surprising that there are not many references to the benefits that the emperors effectively brought to Egypt, such as the silting of the land for farming, and even the fact that they instituted games and continued to put up public buildings and temples, where they posed with the clothes and attributes of the Pharaohs or the Egyptian gods. This was, after all, the compensation that the Roman state gave to the provinces it annexed. And this kind of information is not to be sought in literary texts, but in the data provided by archaeology and epigraphy.

However, in literature there is some information, which deserves to be reflected upon. One example will suffice. Suetonius (Aug. 98.2) tells the following story: close to the end of his life, Augustus was walking at the shore of the Bay of Puteoli, when sailors and passengers from an Alexandrian ship which had just docked went towards him, dressed in white, crowned with flowers and burning incense. They wished him the greatest happiness, and addressed him the most laudatory praise. They assured him that it was thanks to him that they were alive, that they could sail, and enjoyed full freedom and the right to their property. Augustus was extremely flattered by the tribute, and gave forty gold coins to each 
member of his entourage to spend, entirely, in the purchase of Alexandrian goods. We do not want (and indeed are not able) to say if this story is true or not, but, running the risk of looking at antiquity through the prism of political propaganda, which causes and justifies everything, this whole episode seems to expose one of those moments when a supposedly spontaneous outpour of support is enacted. Augustus, even though he did not have long to live, was fully aware of what these gestures mean in terms of power consolidation and public image enhancement. It should be added here that Augustus supposedly said that his desire was that the Romans used the Greek pallium and the Alexandrians the Roman toga. Nothing is more eloquent on the lines of fusion between the two people, although one of them is subjugated and the other is the conqueror. The complex process of Romanisation advanced in this way.

\section{THE ATTRACTION OF ALEXANDRIA AND EGYPT AMONG THE ROMANS}

There is quite a lot of information that reveals the attraction that Alexandria and Egypt exerted on the Romans, particularly those who loved culture - and this despite all the distrust and xenophobia that prevailed in Rome for this strange people with the most unusual habits.

The desire to go to (or settle in) Alexandria is documented for several important characters of Roman history, and most concretely for the emperors. Of these, there were those who went to Egypt primarily for political reasons and those who also had the desire to see the monuments and culture of the prouincia, as did Hadrian: a man of culture and with insatiable intellectual curiosity, he went to Egypt, sailed up and down the Nile (S.H.A., Hadr. 14.5; 20.1-2), saw what was most important to visit, and then commemorated the beauty and fascination of these places in his magnificent uilla of Tibur, where we can still admire the Garden of Canopus and the temple of Serapis.

In the texts consulted one final point calls our attention: the use of religion for political ends, when the princeps worshipped Egyptian gods, using visits to the temples for political propaganda among the local population.

Let us have a look at an episode where Vespasian was the protagonist. While in Alexandria and before heading to Rome to take over the empire, Vespasian wished to consult Serapis to know if imperial power was guaranteed for him. He left his whole entourage behind to enter alone in the temple of the god, and, when he turned back after having prayed at length, it seemed to him that he saw the freedman Basilides offering him, after the manner of the Egyptians, verbenas, wreaths, and cakes. When he revealed this wondrous event, everybody assured him that Basilides could not possibly be there, because he was far away and in the grips of rheumatism, unable to move. This is the version of Suetonius (Vesp. 7.2), who adds that soon afterwards Vespasian received the news that Vitellius' troops had been 
defeated in Cremona, and Vitellius himself had been killed in Rome. As far as propagandistic manipulation goes, there could not be a finer possible staging. Vespasian wants to go alone - witnesses could be bothersome if they declared they had seen nothing. The portent conferred divine confirmation on Vespasian as predestined to govern the empire. On the other hand, that it was an Alexandrian freedman to appear to Vespasian, and with all the insignia of honour peculiar to this province, showed a divine ordinance that Egypt should remain subservient to Roman power, and to this particular emperor.

The same episode is reported by Tacitus in the Historiae (4.82). He too (both authors would undoubtedly have had a reason to underline this) notes that Vespasian ordered everybody to leave the temple and entered it alone. Concentrated in his prayer, he saw on his back one of the notables of Egypt, Basilides, who, he was aware, was sick and away from Alexandria. Still - to give greater credibility to the miracle, the sceptics would say - he later asked everyone if they had seen him in the temple or in the city, and he ordered cavalry soldiers to make sure that Basilides was eighty miles (and that was many days) away. Obviously, the portent was interpreted as a sign of power being attributed to Vespasian and being sanctioned by the deities, given the etymology of the name Basilides (from the Greek basileus, king).

Tacitus (Hist. 4.81) and Suetonius (Vesp. 7.2) also coincide in the telling of other prodigies, in which the gods strive to reveal their support of Vespasian and the supernatural gifts that distinguish him. This is the case of the cure of a blind man and a cripple, also in Alexandria - the land fertile in wonders and whose people, says Tacitus, are dedita superstitionibus more than all others. The blind man and the cripple went to Vespasian, ensuring him that, in dreams, the god Serapis had told them that Vespasian would be able to heal them, if he put a little of his saliva on the eyelids of the blind man, and stepped with his foot on the defective leg of the cripple. In a stroke that lends psychological credibility to the behaviour of Vespasian, both authors refer to the first reaction he had, which was to refuse, even laughing at the suggestion. Eventually, however, he yielded, and the miracle took place to confirm the destiny of the first Flavian emperor. The reader cannot but notice some details of this episode, such as Tacitus' reference to the fact that the astonishing healings happened in the presence of a crowd. Once again, religion served as the basis for political ascent and to garner the support of the masses.

One figure of the Julio-Claudian imperial family was linked to Alexandria and Egypt in a way which we deem driven more by cultural rather than political reasons. We speak of Germanicus. In the year 19, Tacitus tells us that he decided to enter Egypt cognoscendae antiquitatis (Ann. 2.59), although invoking as a pretext issues relating to the management of the province. With the opening of the silos he made the price of grain drop, thus gratifying and appeasing the people in a time of hunger and scarcity. In Alexandria he led a life very pleasing to the people: he went without an escort, wore clothes and shoes in the Greek way - an attitude that can be interpreted as a result of both his intention to become agree- 
able to the Alexandrians and his wish to go as unnoticed as possible. Germanicus knew that he had entered Egypt without the consent of Tiberius. And when Tiberius found out about it, he complained of the affront to the Senate (Suetonius, Tib. 52.2) and severely criticised Germanicus for the indignity of wearing the pallium, when he was meant to wear exclusively the toga, and, above all, for having infringed the instituta of Augustus. Tiberius' animosity against his adopted son grew bigger every day. Unaware of the criticisms hanging over him, Germanicus went through Egypt, as was his desire, visiting the most beautiful or historically important places. He departed from Canopus and went up the Nile. He saw Thebes, admired the hieroglyphics on the monuments, wanted to have the script deciphered for him, visited the Colossus of Memnon, the pyramids, the artificial lakes that received the waters of the Nile, the island of Elephantine, Syene (which is now the beautiful Aswan). In a word, a journey in which we imagine his awe at the wonders which still impress us so much today. Tacitus does not mention, however, an episode which took place during this trip, when Germanicus visited Memphis. The temple of the Apis bull, which he naturally wanted to visit, was located here. Whoever went to this temple used to feed the bull and gather, from the animal's reaction, positive or adverse omens. The bull turned his snout away from Germanicus, and refused to eat the food that he was giving him in his hand. The account is from Pliny ( $N H$ 8.185), who notes that the bad omen was confirmed shortly afterwards by the death of Germanicus, which by all accounts seems to have been ordered by Tiberius. Tacitus, who in the Annales comes clearly in favour of Germanicus and paints with dark colours the character of Tiberius, as an underhanded and cruel despot, suppresses this episode, as he would not have wanted to recall that in Egypt the gods could just as much ordain emperors as announce a tragic destiny. So we are left with the benevolent image of a Germanicus who is generous, educated, awake to what is most beautiful in the world, willing to break the toughest rules to satisfy his intellectual curiosity. For the reader he becomes, thus, a kind of symbol for everybody who is left enchanted by the mystery and grandeur of the Egyptian civilisation. 